\title{
Farmers' Perception and Indigenous Knowledge for Natural Resources Management, Abo-Wonsho Woreda, Southern Ethiopia
}

\author{
Melku Dagnachew Alemu \\ Department of Natural Resources Management, Wolaita Sodo University, Wolaita Sodo, Ethiopia \\ Email: melku1980@gmail.com
}

How to cite this paper: Alemu, M.D. (2019) Farmers' Perception and Indigenous Knowledge for Natural Resources Management, Abo-Wonsho Woreda, Southern Ethiopia. Agricultural Sciences, 10, 14051422

https://doi.org/10.4236/as.2019.1011103

Received: October 7, 2019

Accepted: November 3, 2019

Published: November 6, 2019

Copyright $\odot 2019$ by author(s) and Scientific Research Publishing Inc. This work is licensed under the Creative Commons Attribution International License (CC BY 4.0).

http://creativecommons.org/licenses/by/4.0/

c) (i) Open Access

\begin{abstract}
In this study, the roles of indigenous knowledge and farmers' perception of natural resources management were analyzed. A total of seventy households were selected by simple random sampling with replacement method for collection of data. Formal interviews were conducted to the $5 \%$ plus of households in the study area in addition to the focus group discussions and qualitative field observations. It was expressed by $98.6 \%$ of the total respondents that "Sera" which is the traditional practice has being used to manage natural resources in the study area. In the "Sera" systems, individuals are excluded a punishment from any kind of social interaction in a response to their unlawful action in the community natural resources. It was indicated by $84.3 \%$ of respondents that deforestation and related problems are the major challenges including grazing and shortage of farm size for the management of the culturally protected forest in the study area. The majority of the respondents (77.1\%) believed that soil fertility decline in the study area. Development of effective participatory forest management and encouragement and supporting the traditional method of natural resources management is required to ensure the preservation and protection of these areas essential to ecosystem service provision, provide high biodiversity value and cultural heritage, and maintain the sustainability of culturally protected forest.
\end{abstract}

\section{Keywords}

Indigenous Knowledge, "Sera”, Participatory Forest Management, Abo-Wonsho, Southern Ethiopia

\section{Introduction}

The Local knowledge, also termed Indigenous Knowledge (IK), may be defined 
as tacit knowledge of a community which is either generated locally or imported and transformed to be incorporated in the way life of the community [1]. It has a dynamic nature, adaptive capacity, flexibility and site-specificity which make it unique and important [2]. There is growing importance in identifying, understanding and using local knowledge in natural resource management studies [3]. If a knowledge system refers to the skill, experience, and insight of local people then its relevance makes it more suitable for integration in natural resource management endeavors.

Indigenous people have developed, and continue to develop indigenous knowledge systems which encompass sustainable management of natural resources [4]. Thus, the indigenous knowledge systems are a significant resource which would contribute to the increased efficiency, effectiveness and sustainability in environmental conservation among rural communities of developing countries in particular [5]. Different Studies in Ethiopia reported that the relationship between indigenous knowledge and the local natural resources management which comprises informal institutions, in terms of rules and norms, about how to treat the environment, use resources as well as comprising a particular view that governs as to the local indigenous knowledge rule. For instance, the importance of local knowledge in natural resource management has been reported in soil and water conservation in Konso [6], stone bund in north Shoa [7], irrigation practices in Tigray [8] and forest management in Oromia [9].

The study by [10] revealed that the role of indigenous knowledge of Oromo people on natural resources management maintained the wise management of natural resources. It was reported that forests around churches are most protected than elsewhere in northern Ethiopia as people consider the place as the holiest religiously [11]. Furthermore, he noted that these forests are sanctuaries for different organisms, a remnant of the past times forest ecosystem and can serve as a springboard to restore the forest ecosystem. Similar protected areas are known in the Southern Ethiopia and Abo-Wonshu is one. Abo-Wonshu is Sidama's cultural heritage and exemplary natural protection endeavor. It is believed that the area has been under protection for the last 21 generations (Oral communication with cultural leaders and elders). The area is covered with trees while the surrounding show diminished perennial cover and obviously, there is a threatening situation to Abo-Wonshu. However, little is known about the cultural practice, the community values and perceptions, the benefits, limitations and constraints for sustained use. Moreover, there is no documented evidence of how and why such systems are maintained and the impact in the physical environment in general. In particular, study concerns on the perception of the community on natural resource conservation around and in a culturally protected forest area. The main objective of this study was to investigate farmers' indigenous knowledge on natural resource conservation and management in the AboWonsho culturally protected forest area, Abo-Wonsho Woreda, Southern Ethiopia. Specific objectives were: 1) To identify farmers' local knowledge and un- 
derstanding on Abo-Wonsho culturally protected forest; 2) To examine farmers' perception on management of Abo-Wonsho and farm management practices and soil fertility; 3) To draw some recommendations on appropriate measures that should be undertaken.

\section{Materials and Methods}

\subsection{Description of the Study Area}

\subsubsection{Location}

Abo-Wonshu is located in the outskirt of Bokasso town which is the capital of Wonsho woreda in Sidama Zone, Southern People's National Regional States, Ethiopia. It is about $12 \mathrm{~km}$ to the east of Yirgalem town (Figure 1), and $329 \mathrm{~km}$ from Addis Ababa. Geographically, it is located between $06^{\circ} 39^{\prime} 30^{\prime \prime}$ to $06^{\circ} 46^{\prime} 30^{\prime \prime}$ Northlatitude and $38^{\circ} 20^{\prime} 30^{\prime \prime}$ to $38^{\circ} 34^{\prime} 30^{\prime \prime}$ Eastlongitude with an approximate altitudinal range from $1978 \mathrm{~m}$ (West end, lower) to $2149 \mathrm{~m}$ (East or upper end) above sea level. The area is protected as a sacred place by the Sidama people. The story goes back so many decades and traditionally believed to go as far back as 21 generations.

\subsubsection{Climate, Geology, and Soil}

The study areas are characterized by mean annual rainfall and mean annual temperature ranging from $832 \mathrm{~mm}$ to $1658 \mathrm{~mm}$ and $18^{\circ} \mathrm{C}-21^{\circ} \mathrm{C}$, respectively.

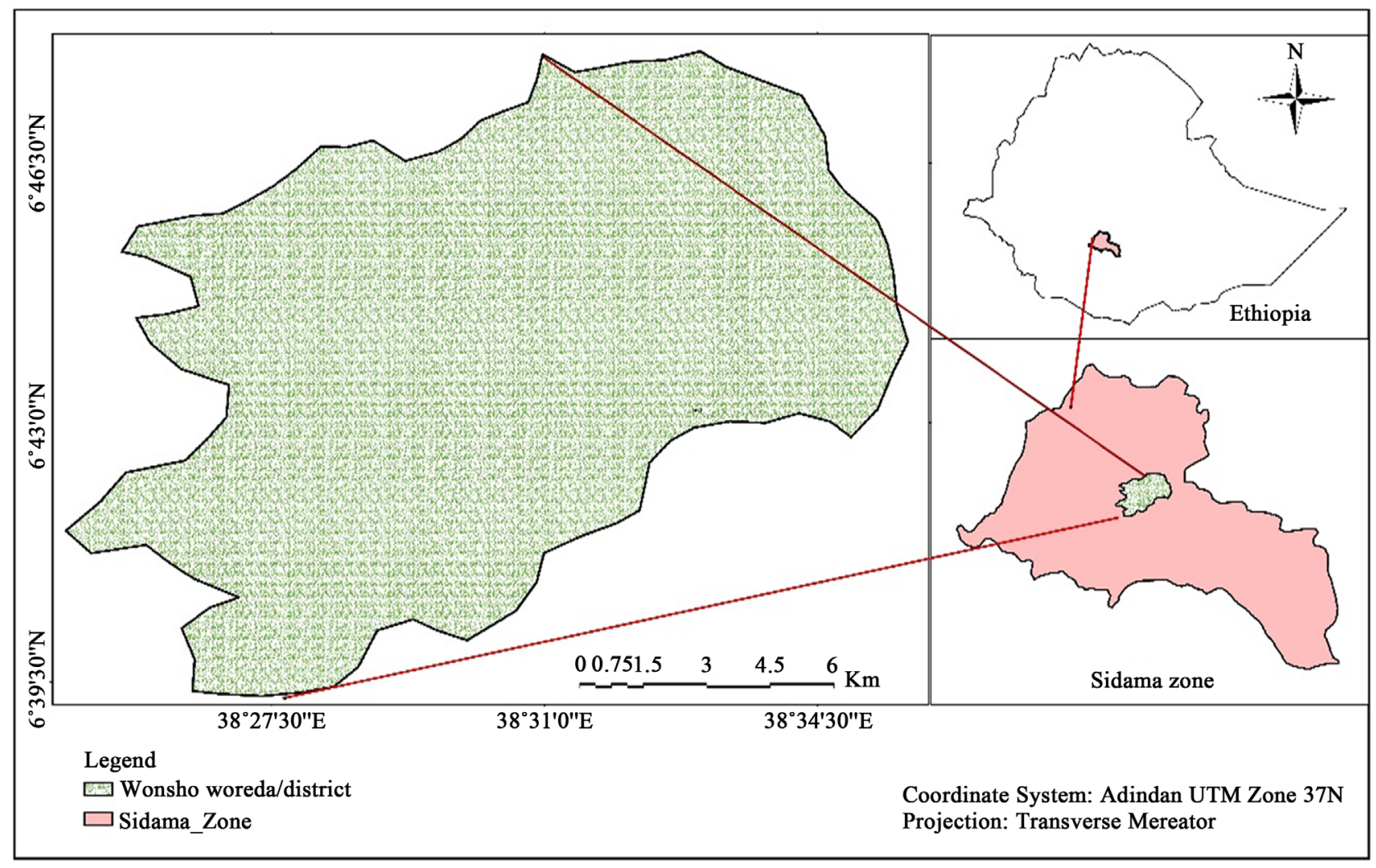

Figure 1. The study map of Abo-Wonsho Woreda, Sidama Zone, Ethiopia. 
The pattern of rainfall distribution is bimodal. The short rainy season lasts from mid-November to February whereas the long rainy season is from March to May and it extends from August to October [12]. According to the Sidama Zone Finance and Economic Development Sector [13], the Wonsho Woreda can be divided into four climatic zones as "Wet Dega", "Moist woyna Dega", "Wet woyna dega", and "wet Kola" on the basis of altitudinal and annual rainfall variations. Accordingly, the study site is observed to be "Wet-Woyna Dega" (Wet mid-highland).

\subsubsection{Farming System and Land Use}

Agriculture in the area is characterized by subsistence mixed crop-livestock farming. Most of the area around the homestead is covered with perennial crops mainly Enset (Ensete ventricosum), which is used as a staple food throughout the year and income source. Coffee (mainly Coffee arabica) and Chat (Catha edulis) are also widely practiced. Fruit trees such as Papaya, Persea Americana (Avocado) and Mango (Mangifera indica) are also cultivated. Grazing is carried out mainly on the communal grazing land, protected forest land, and front yard fields, where cattle used to graze in the morning and afternoon. Land use in this paper refers to the existing use of land with different management practices. The description of each land use type is presented as follow:

Protected Forest land is the land use types in which the area is protected culturally for the last 21 generations (Figure 2). This forest is composed of varies indigenous trees, shrubs, and bushes as well as grasses species. The forest comprises of different endemic trees and animal species. Some of the most common vegetation types are Podocarpus falcatus or P. gracilior (Zigba), Strychnos spinosa (Dokma), Croton macrostachyus (Bisana), Arundinaria alpine (Mountain bamboo or Kerkeha locally), Pouteria adolfi-friedericii (or Aningeriaadolfi-friedericii, Keraro), Juniprus procera (Tid), Cordia africana(Wanza), Prunus Africana (Tikur-enchet), Euphorbia candelabrum (Kulkual) Mellettia ferruginea (Birbira), Vernonia amygdalina (Grawa), etc. [14].

Open grassland is the land use type predominantly of very short grasses and situated within the protected area as shown in Figure 3. This land use system is denuded of trees, shrubs and bushes and open for grazing. Protected forest and open grassland are both within the culturally protected area and their main difference is vegetation cover and free access for open grazing.

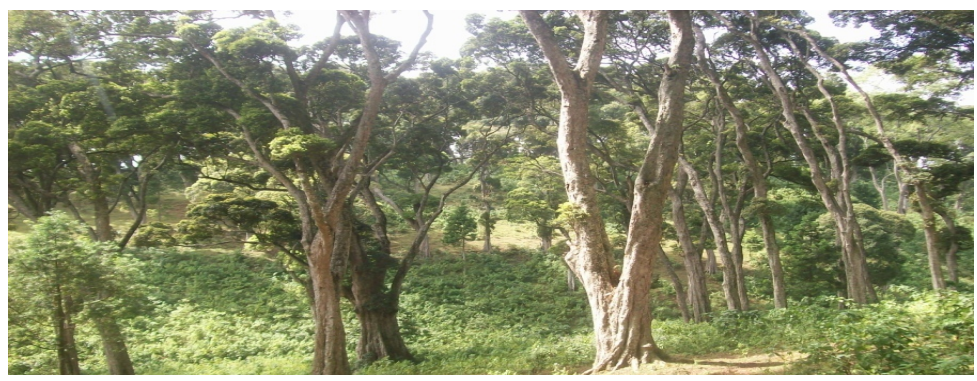

Figure 2. Culturally protected forest land. 
Farmland is the land use type which is characterized by cultivation crops (both perennials and annual crops). The main cropping system is a mixed cropping system where perennial crops such as Coffee (Coffee Arabica), Enset (Ensete ventricosum), and Chat (Catha edulis) are the dominant ones. Farmers usually use live fence around their farmland for shade, firewood, fodder, and soil fertility improvement. This land use system consists of a complex multi-strata system in which crops and trees are growing in the same plot of land as shown in Figure 4.

Grazing land is also one of land use systems where a group(s) of farmers are using for grazing their cattle as a common land, which is considered as communal grazing land (Figure 5). Other than direct inputs of cow dung and urine to the grazing land, no other soil inputs are applied to the grazing land by the owners.

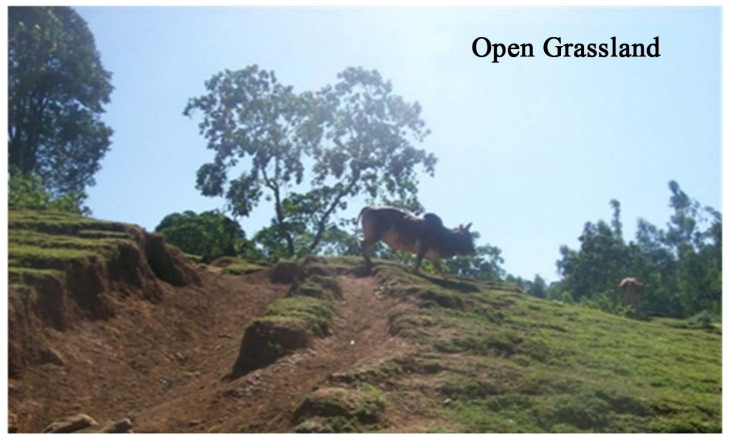

Figure 3. Open grassland within the protected forest area.

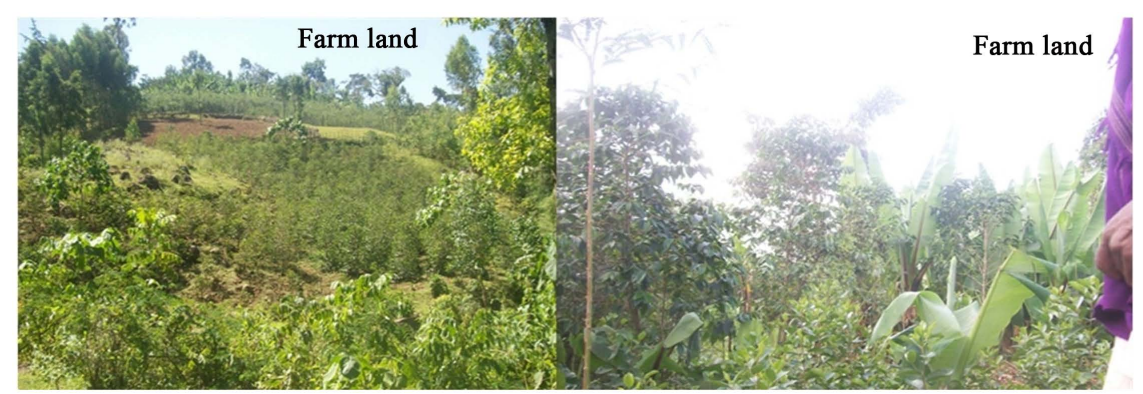

Figure 4. Perennial crop dominated farm land.

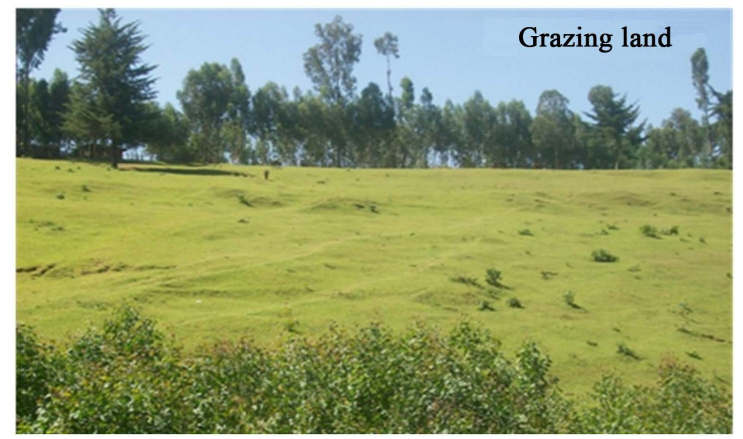

Figure 5. Communal grazing land. 


\subsection{Methods}

\subsubsection{Household Survey Methods}

Data and information about perceptions of farmers were collected using formal interviews with the head of the household, focus group discussions with elders and community or cultural leaders and by means of qualitative field observations during 2017. Farmers were randomly selected for interview (using simple random sampling with replacement) from lists obtained from community leaders and "kebele" development agents in the study area. Seventy farmers from Bokasso kebele (from six villages such as Bokasso, Holona, Wonsho, Wondicho, Gowodene) were interviewed, which ensured that at least 5 percent of farmer households were sampled. When a farmer was unavailable or unwilling to be interviewed a substitute was selected. Both open-ended and closed questions were used in the household interview processes. Prior to conducting the full survey, preliminary survey was done to 10 farmers to evaluate the questionnaire, and based on these responses some minor modifications were made in order to get better information for the study. The test survey period permitted standardization of interview technique for all interviewers. Both closed and open ended questionnaires were employed.

Focus group discussion with selected farmers (elders and cultural leaders) during the field visit was undertaken as a means of cross-checking the individual farmer responses.

The field observation was made in a position that allows to capture greatest diversity or ecosystems and land use, extent of degradation of land resources including farmlands, grazing lands and forests, and current land management practices etc. Problems of land degradation, and land management practices and indicators of soil degradation were carefully observed and recorded. From the farmers' responses lists (classified by type of factors and by whether factors are internal or external) of perceived indicators, reasons and known conservation measures were perceived [15].

\subsubsection{Data Analysis}

The distribution and frequency of the farmers' perceptions were explored using descriptive statistical analysis using Statistical Package for Social Studies (SPSS) Statistics for Windows release version 20.

\section{Results and Discussion}

The household characteristics of the study area were indicated in Table 1 and Table 2. The age of respondents ranged from $30-92$ with an average of 50.5 years. The average males and female in the household were found to be 4.49 and 4.29 respectively.

In the study area, the farmers' land holding size ranges from 0.25 ha to 3.67 ha with an average of 1.14 ha. The majority of farm size lies between $0.51-1$ ha (38.6\%), followed by 0 - 0.5 ha (22.9\%) and minimum was found to be $\geq 2.1$ ha (8.6\%; Table 2). The major source of livelihood for the households (100\%) was 
Table 1. Household characteristics of the respondents.

\begin{tabular}{cccc}
\hline Categories & Min. & Max & Mean \pm SEM \\
\hline Age of the respondents & 30 & 92 & $50.49 \pm 1.35$ \\
Household family size & 3 & 19 & $8.77 \pm 0.382$ \\
Number of males in the HH & 1 & 10 & $4.49 \pm 0.225$ \\
Number of females in the HH & 1 & 10 & $4.29 \pm 0.253$ \\
Children less than 5 years & 0 & 4 & $1.20 \pm 0.116$ \\
Children between 6 and 14 yrs & 0 & 10 & $3.14 \pm 0.246$ \\
Adults 15 to 64 years & 1 & 11 & $4.24 \pm 0.250$ \\
Age $\geq 65$ years & 0 & 2 & $0.17 \pm 0.057$ \\
Disabled & 0 & 0 & $0.00 \pm 0.000$ \\
Household farm size (ha) & 0.25 & 3.67 & $1.14 \pm 0.078$ \\
Number of cattle & 0 & 36 & $5 \pm 0.562$ \\
Number of equines & 0 & 2 & $0.143 \pm 0.047$ \\
Number of sheep & 0 & 10 & $0.94 \pm 0.200$ \\
Number of Goat & 0 & 12 & $0.61 \pm 0.195$ \\
Number of Chicken & 0 & 10 & $2.26 \pm 0.291$ \\
\hline
\end{tabular}

${ }^{*}$ Cattle include cows, heifers, and bulls; Source: Field Survey, 2017.

Table 2. Frequency (N) and Percentage (\%) distribution of Age category, Educational level and farm size $(\mathrm{Ha})$ of respondents in the study area.

\begin{tabular}{|c|c|c|c|c|c|}
\hline Age category of respondents & $\mathrm{N}$ & $\%$ & Farm size of the HHs (ha) & $\mathrm{N}$ & $\%$ \\
\hline $30-40$ yrs & 17 & 24.3 & $0-0.5$ & 16 & 22.9 \\
\hline $41-50$ yrs & 24 & 34.3 & $0.51-1.0$ & 27 & 38.6 \\
\hline $51-60$ yrs & 16 & 22.9 & $1.1-1.5$ & 14 & 20.0 \\
\hline $61-70$ yrs & 12 & 17.1 & $1.51-2.0$ & 7 & 10.0 \\
\hline$\geq 71 \mathrm{yrs}$ & 1 & 1.4 & $\geq 2.1$ & 6 & 8.6 \\
\hline Total & 70 & 100 & Total & 70 & 100.0 \\
\hline Educational level of the Respondents & & & Changes in the $\mathrm{HH}$ farm size & & \\
\hline Illiterate & 28 & 40.0 & Same & 29 & 41.4 \\
\hline read and write & 16 & 22.9 & Decreasing & 31 & 44.3 \\
\hline Grade level & 26 & 37.1 & Increasing & 10 & 14.3 \\
\hline Total & 70 & 100.0 & Total & 70 & 100 \\
\hline Income Category (ETHB) & & & Income Category & & \\
\hline $0-1000$ & 11 & 15.7 & $5001-10,000$ & 9 & 12.9 \\
\hline $1001-2000$ & 9 & 12.9 & $10,001-20,000$ & 9 & 12.9 \\
\hline $2001-3000$ & 12 & 17.1 & $\geq 20,000$ & 10 & 14.3 \\
\hline $3001-5000$ & 10 & 14.3 & total & 70 & 100 \\
\hline \multicolumn{6}{|l|}{$\begin{array}{l}\text { Main source of Livelihood } \\
\text { for the household }\end{array}$} \\
\hline On-farm & 70 & 100 & & & \\
\hline Off-farm & 0 & 0 & & & \\
\hline
\end{tabular}

EthBirr, Ethiopian Birr; 1US\$ = 27.22 ETHB; Source: Field Survey, 2017. 
on-farm activities. The majority of the respondents (77.1\%) have used crop residues and tree and/or Enset leaves for their animals as fodder, while 22.9 percent haven't used it either because of lack of the resources or they only keep their animals in the protected forest and grazing land. Most farmers used to graze their animal in the communal grazing land (51.4\%), private grazing land (47.1\%) and protected forest land (64.3\%, Table 3$)$. While other farmers $(35.7 \%)$ were not used the protected forest for grazing their animal due to 1) fear of Abo spirit 2) some farmers live far from the protected forest and 3) fear of parasite while their cattle drink water from the rivers found in the protected forest. However, the protected forest is free for grazing and has been served as open access resources that every farmer has the right to keep their animal in the holy place, Abo-wonsho. About Ninety seven percent of the respondents have raised domestic animals, while only $2.9 \%$ of the respondent didn't have livestock. However, in the last two decades the trend of the size of the livestock in the majority of respondents (82.9\%) was decreased due to shrinkage of grazing land, inherited to their children and selling for daily consumption, while $11.4 \%$ showed increasing and the remaining $5.7 \%$ remain the same (Table 3 ).

\subsection{Farmers' Awareness and Natural Resources Management of Abo-Wonsho}

Local knowledge (LK) has great significance and refers to the use of resources and the management of natural habitats and agroecosystems [16]. In this study it was explained that the area was established by Abo, a person who has been believed to come from abroad and settled in the current place called "Abo-Wonsho".

Table 3. Frequency (N) and percent (\%) of the major sources of animal feed and major reasons for the change in farm size and livestock population in the study area.

\begin{tabular}{|c|c|c|c|c|c|c|}
\hline \multirow{2}{*}{ Major sources of feed for animals } & \multicolumn{2}{|c|}{ Frequency $(\mathrm{N})$} & \multicolumn{2}{|c|}{ Percent (\%) } & \multicolumn{2}{|c|}{ Total } \\
\hline & Yes & No & Yes & No & $\mathbf{N}$ & $\%$ \\
\hline Crop Residues and tree leaves & 54 & 16 & 77.1 & 22.9 & 70 & 100 \\
\hline Communal grazing land & 55 & 15 & 51.4 & 48.6 & 70 & 100 \\
\hline Private Grazing land & 14 & 56 & 47.1 & 52.9 & 70 & 100 \\
\hline Grazing in the protected forest & 45 & 25 & 64.3 & 35.7 & 70 & 100 \\
\hline Are you raising domestic animals? & 68 & 2 & 97.1 & 2.9 & 70 & 100 \\
\hline \multicolumn{7}{|l|}{ Reasons and trends for the change in farm sizes } \\
\hline Neither shared, bought nor sold land (Same) & \multicolumn{2}{|c|}{29} & \multicolumn{2}{|c|}{41.4} & & \\
\hline Sold and shared to children (Decreasing) & \multicolumn{2}{|c|}{31} & \multicolumn{2}{|c|}{44.3} & & \\
\hline Bought through contract (Increasing) & \multicolumn{2}{|c|}{10} & \multicolumn{2}{|c|}{14.3} & & \\
\hline \multicolumn{7}{|l|}{ Livestock population changes/trends } \\
\hline Same & \multicolumn{2}{|r|}{4} & \multicolumn{2}{|c|}{5.7} & & \\
\hline Decreased & \multicolumn{2}{|c|}{58} & \multicolumn{2}{|c|}{82.9} & & \\
\hline Increased & \multicolumn{2}{|r|}{8} & \multicolumn{2}{|c|}{11.4} & & \\
\hline
\end{tabular}


The majority of respondents (92.9\%) have known about the history and cultural practices of "Abo-Wonsho", while only 7.1\% didn't know how and why such systems have been protected for many generations. Moreover, most of the respondents $(64.3 \%)$ believed that the area has been well maintained and protected, while $35.7 \%$ of the respondents didn't agree and they were able to mention some of the indicators of threatening situations like expansion of open land, remaining of tree remnant, debarking of tree stems to dry for fuel wood and construction materials, and soil erosion were the pressing problems occurred in the forest (Table 4). The protection and preservation of forest as a cultural knowledge and heritage is an uphill battle for the societies [17].

Majority of the respondents, $74.3 \%$, believed that trees are still alive as a result of spiritual protection of Abo and there is a remarkable regeneration of seedling underneath. It was expressed by the entire surveyed household believing that reforestation/Afforestation or replacement of dead trees with new seedlings within the protected forest and any kind of human induced management is not allowed for the sake of keeping the word of Abo and culturally leaders. Local participation can be more effective if the community understands the value of its participation [18]. The majority of the respondents (84.3\%) understood that the problem of deforestation has been increased from time to time. In contrast, 12.9 percent of the respondents believed that the problem of deforestation has been

Table 4. Frequency and percent of farmers' perception and their understanding and knowledge about Abo-Wonsho.

\begin{tabular}{|c|c|c|c|c|c|c|}
\hline \multirow{2}{*}{ Variables } & \multicolumn{2}{|c|}{ Frequency $(\mathrm{N})$} & \multicolumn{2}{|c|}{ Percent (\%) } & \multicolumn{2}{|c|}{ Total } \\
\hline & Yes & No & Yes & No & $\mathrm{N}$ & $\%$ \\
\hline Knowledge about Abo-Wonsho & 65 & 5 & 92.9 & 7.1 & 70 & 100 \\
\hline $\begin{array}{l}\text { Do you think Abo-Wonsho } \\
\text { has been well Maintained? }\end{array}$ & 45 & 25 & 64.3 & 35.7 & 70 & 100 \\
\hline In your opinion, are trees still alive? & 52 & 18 & 74.3 & 25.7 & 70 & 100 \\
\hline Afforestation/reforestation/replacement & 0 & 70 & 0 & 100 & 70 & 100 \\
\hline \multicolumn{7}{|l|}{ Cover of Abo-wonsho has been } \\
\hline Same & \multicolumn{2}{|c|}{33} & \multicolumn{2}{|c|}{47.1} & & \\
\hline Decreasing & \multicolumn{2}{|c|}{26} & \multicolumn{2}{|c|}{37.1} & & \\
\hline Increasing & \multicolumn{2}{|c|}{11} & \multicolumn{2}{|c|}{15.7} & & \\
\hline Total & \multicolumn{2}{|c|}{70} & \multicolumn{2}{|c|}{100} & & \\
\hline \multicolumn{7}{|l|}{ Problem of deforestation has been } \\
\hline Same & \multicolumn{2}{|c|}{2} & \multicolumn{2}{|c|}{2.9} & & \\
\hline Decrease & \multicolumn{2}{|c|}{9} & \multicolumn{2}{|c|}{12.9} & & \\
\hline Increase & \multicolumn{2}{|c|}{59} & \multicolumn{2}{|c|}{84.3} & & \\
\hline Total & \multicolumn{2}{|c|}{70} & \multicolumn{2}{|c|}{100} & & \\
\hline No. generations & \multicolumn{2}{|c|}{$\operatorname{Min}=10$} & \multicolumn{2}{|c|}{$\operatorname{Max}=21$} & \multicolumn{2}{|c|}{ Av. $\sim 6.16$} \\
\hline
\end{tabular}


decreased, while 2.9 percent believed that the problem of deforestation has been remained the same (Table 4). This indicates that most of the respondents were aware of the problem of natural resource degradation, however, they preferred to maintain their culture and beliefs; which may need intervention of the regarding stakeholders for the sustainability of the resource. The respondents were also asked whether the cover of the forest has been changed or not. Accordingly, most of the respondents $(47.1 \%)$ perceived that the forest cover remained the same; in contrast 37.1 percent believed that the cover of the forest has been decreased due to human and animal interference, while the remained $15.7 \%$ of the respondent agreed that the forest cover has been increased (Table 4) as a result of natural regeneration. As community-based natural resource management (CBNRM) is a major global strategy for the sustainable of management natural resources [19], attention should be given for awareness creation.

\subsection{Indigenous Knowledge and Participatory Management of Abo-Wonsho Forest}

Unique culture and cultural practices of society have a great importance for natural resource management. Understanding how indigenous people manage their natural resources, supporting the indigenous knowledge with scientific way can provide a basis for formulating appropriate policies for natural resources management that benefits them while preserving their cultural beliefs [20]. In the study area, the responsibility of managing and protecting the forest falls fully on the shoulder of cultural leaders named as "Gana", "Woma", "Gadala" and "Karicho". Any kind of management activities like reforestation, soil and water conservation activities are not allowed in the culturally protected forest due to cultural reasons. The survey revealed that most of the respondents $(95.7 \%)$ were aware of the prohibition of cutting of trees and 98.6 percent believed that cultivation has not been allowed in the sacred place. However, some farmers (4.3\%) weren't aware of the prohibition of cutting of trees and 1.4 percent weren't aware of the prohibition of cultivation in the protected forest (Table 5). On the other hand, most farmers (78.6\%) were also believed that expansion of farm land towards the protected forest was strictly forbidden; however, 21.4 percent weren't aware of the rules as a result these farmers have been expanding towards the protected forest. The field observation also revealed that farmers around the protected forest were expanding their farm land towards the forest and it was observed that some farmers were even crossing the rivers and planting trees like Eucalyptus species for construction and fuel wood purposes. In order to overcome such and other illegal activities, the cultural leaders have developed a mechanism called "Sera". "Sera" is a Sidama's word meaning the exclusion of individuals from any kind of social interaction and from the participation of any community organizations as a whole and punishing those farmers who violated the cultural rule. The traditional cultures and knowledge are very important for both the nature and society [21]. Most of the surveyed households (98.6\%) have 
Table 5. Frequency (N) and percent (\%) of various indicators, consequences of deforestation and forest management practices in the study area.

\begin{tabular}{|c|c|c|c|c|c|c|}
\hline \multirow{2}{*}{ Variables } & \multicolumn{2}{|c|}{ Frequency $(\mathrm{N})$} & \multicolumn{2}{|c|}{ Percent (\%) } & \multicolumn{2}{|c|}{ Total } \\
\hline & Yes & No & Yes & No & $\mathrm{N}$ & $\%$ \\
\hline Rights to cut trees from the protected forest & 3 & 67 & 4.3 & 95.7 & 70 & 100 \\
\hline Right to Cultivate in the protected forest & 1 & 69 & 1.4 & 98.6 & 70 & 100 \\
\hline Expansion of farmland to the protected forest & 15 & 55 & 21.4 & 78.6 & 70 & 100 \\
\hline Cultural rules to control illegal activities 'Sera' & 69 & 1 & 98.6 & 1.4 & 70 & 100 \\
\hline Right to graze animals in the protected forest & 70 & 0 & 100 & 0 & 70 & 100 \\
\hline $\begin{array}{l}\text { The impact of grazing on } \\
\text { forest \& soil degradation }\end{array}$ & 26 & 44 & 37.1 & 62.9 & 70 & 100 \\
\hline $\begin{array}{l}\text { The problem of deforestation } \\
\text { in the protected forest }\end{array}$ & 32 & 38 & 45.7 & 54.3 & 70 & 100 \\
\hline \multicolumn{7}{|l|}{ Indicators of deforestation in the protected area } \\
\hline $\begin{array}{l}\text { Soil erosion, cutting of trees, branches, } \\
\text { wildlife migration, debarking }\end{array}$ & \multicolumn{2}{|c|}{15} & \multicolumn{2}{|c|}{21.4} & & \\
\hline Expansion of open field, soil erosion & \multicolumn{2}{|c|}{17} & \multicolumn{2}{|c|}{24.3} & & \\
\hline No reason & \multicolumn{2}{|c|}{38} & \multicolumn{2}{|c|}{54.3} & & \\
\hline \multicolumn{7}{|l|}{ The main consequence of deforestation } \\
\hline Soil Fertility decline & 54 & 16 & 77.1 & 22.9 & 70 & 100 \\
\hline Accelerating soil erosion & 45 & 25 & 64.3 & 35.7 & 70 & 100 \\
\hline Shortage of grazing land & 44 & 26 & 62.9 & 37.1 & 70 & 100 \\
\hline Shortage of fire wood & 46 & 24 & 65.7 & 34.3 & 70 & 100 \\
\hline Loss of forest tree species & 37 & 33 & 52.9 & 47.1 & 70 & 100 \\
\hline Loss of wild animals species & 46 & 24 & 65.7 & 34.3 & 70 & 100 \\
\hline Changing in microclimate & 57 & 13 & 81.4 & 18.6 & 70 & 100 \\
\hline Drying up of rivers and streams & 48 & 22 & 68.6 & 31.4 & 70 & 100 \\
\hline Do you believe deforestation can be controlled? & 70 & 0 & 0 & 100 & 70 & 100 \\
\hline
\end{tabular}

"Sera" is a cultural management system that inhibits the involvement of individual from participation in any aspect of social affairs and absolute exclusion from the community.

accepted and agreed with this cultural rule, while only $1.4 \%$ of the respondents didn't agree and accept this rule (Table 5) following the conversion of cultural beliefs to Christianity. The communities highly respect this rule because of fearing of the spirit of Abo and cultural leaders and it has been believed as the most important instrument for conserving the forest. This is the proof that the religious beliefs are very useful tools in natural resource management [22]. Thus, the trends of religion and believes can continue to be used as a powerful tool for managing the negative impacts of human related pressures on the natural resources [23].

The study revealed that all members of communities (100\%) have the right to 
keep their animals in the protected forest area throughout the year (Table 5). The farmers were asked their opinion about the impact of grazing on the forest and soil degradation. Accordingly, most of the farmers (62.9\%) didn't perceive the impact of grazing on forest and soil degradation which could affect the forest area and affect the diversity as grazing is negatively correlated with forest health [24]. While some of the respondents (37.1\%) were recognized its impact on forest and soil resources and they were able to suggest some solutions to alleviate such problems such as exclusion of animal and human interferences and fencing of the protected forest. Large livestock population can create open fields and destroys the under growth vegetation through grazing and trampling. Livestock-induced disturbances might be among the major factors constraining regeneration of forest species and contributing to the decline of woody species populations and natural regeneration could be scarce, presumably, due to livestock grazing [11].

Generally, 54.3 percent of the surveyed households didn't perceive the problem of deforestation in the protected area and, while 45.7 percent believed and agreed the problem of deforestation in the protected area and were able to give some reasons and indicators of deforestation. Some of the indicators of the problem of deforestation mentioned by the respondents were cutting of trees, wildlife migration, debarking (21.4\%) and expansion of open fields and soil erosion $(24.3 \%$, Table 5$)$. On the other hand, most of the respondents $(84.3 \%)$ believed that the trend of deforestation has been increased, while only $12.9 \%$ believed the problem has been decreased, whereas 2.9 percent of the respondents believed that the problem remained the same (Table 4) in the last two decades. The focus group discussion also revealed that the main causes of deforestation were believed to be lack of fuel wood and alternative energy sources, lack of awareness, poverty, population pressure, lack of integration of cultural and government management system. In the study [11] reported that except around churches and some inaccessible pockets owing to deforestation associated with, mainly, expansion of farmlands, spurred by the rapidly increasing populations of humans and domestic animals, over centuries. In the same way [25] also reported that increase in population size and its dependence on agriculture have forced people to expand cultivation into the forest and marginal lands. They also reported that the traditional practice of free grazing in Ethiopia is also a major cause of land degradation. Most farmers were also aware of the consequence of deforestation and they tried to mention as much consequences as possible. Accordingly, the majority of the respondents believed that soil fertility decline (77.1\%), accelerating soil erosion (64.3\%), shortage of grazing land (62.9\%), shortage of firewood (65.7\%), loss of tree species (52.9\%), loss of wild animals species $(65.7 \%)$, changing in microclimate $(81.4 \%)$, and drying up of rivers and streams $(68.6 \%)$ were the main consequences of deforestation that perceived by the respondents (Table 5). It is widely agreed that deforestation causes a decline in the productive capacity of soils, accelerated erosion, destruction of wildlife 
habitats, and loss of plant genetic diversity [26]. Generally, all the respondents (100\%) believed that the problem of deforestation can be controlled through integration of cultural and modern participatory forest management systems.

\subsection{Farm Management Practices and Soil Fertility}

In recent years the value of traditional knowledge of indigenous people, particularly their traditional environmental knowledge has been recognized. Local communities manage their soil resources through better decision making and local monitoring of their environment [27]. In the study area, most farmers (82.9\%) used mixed cropping system, while few of them (17.1\%) used mono cropping system (Table 6), this was due to the shrinkage of farm size forced them to use mixed cropping system for efficient utilization of their land. As a result, 85.7 percent of the respondents perceived decline of crop production, while 14.3 percent didn't face decline of crop production.

Declining soil fertility is acknowledged as a problem by the vast majority of farmers who experience it on their farms. Most of the respondents (85.7\%) perceived soil fertility decline on their farm land, while 14.3 percent didn't perceive the problem of soil fertility decline on their farm land (Table 6). Farmers were able to mention the major perceived reasons for the decline of soil fertility.

Table 6. Frequency (N) and Percent (\%) of Farmers' perception on various farm management practices and soil fertility.

\begin{tabular}{|c|c|c|c|c|c|c|}
\hline \multirow{2}{*}{ Variables } & \multicolumn{2}{|c|}{ Frequency $(\mathrm{N})$} & \multicolumn{2}{|c|}{ Percent (\%) } & \multicolumn{2}{|c|}{ Total } \\
\hline & Yes & No & Yes & No & $\mathbf{N}$ & $\%$ \\
\hline Application of soil inputs on farmland & 69 & 1 & 98.6 & 1.4 & 70 & 100 \\
\hline Animal manure and household wastes & 70 & 0 & 100 & 0 & 70 & 100 \\
\hline Inorganic fertilizer & 31 & 39 & 44.3 & 55.7 & 70 & 100 \\
\hline Crop residues and/ or tree leaves & 28 & 42 & 40.0 & 60 & 70 & 100 \\
\hline Decline of Crop production & 60 & 10 & 85.7 & 14.3 & 70 & 100 \\
\hline Perception on soil fertility Decline on farm & 60 & 10 & 85.7 & 14.3 & 70 & 100 \\
\hline \multicolumn{7}{|l|}{ Perceived reasons for soil fertility decline } \\
\hline $\begin{array}{l}\text { Shortage of manure, soil erosion, } \\
\text { deforestation, lack of crop rotation }\end{array}$ & 60 & 10 & 85.7 & 14.3 & 70 & 100 \\
\hline Continuous cultivation & 55 & 15 & 78.6 & 21.4 & 70 & 100 \\
\hline Drying of farm fields & 49 & 21 & 70 & 30 & 70 & 100 \\
\hline Increasing price of inorganic fertilizer & 37 & 33 & 52.9 & 47.1 & 70 & 100 \\
\hline \multicolumn{7}{|l|}{ Indicators of soil fertility decline on farmland } \\
\hline Stunted growth of crops & 57 & 13 & 81.4 & 18.6 & 70 & 100 \\
\hline Yield Decline & 56 & 14 & 80 & 20 & 70 & 100 \\
\hline Color change on leaves & 33 & 37 & 47.1 & 52.9 & 70 & 100 \\
\hline Inferior grain quality & 31 & 39 & 44.3 & 55.7 & 70 & 100 \\
\hline
\end{tabular}


Farmers identified "shortage of manure", "soil erosion", "deforestation", "lack of crop rotation" (85.7\%), "continuous cultivation" (78.6\%), "drying of farm lands" (70\%) and increasing of the price of inorganic fertilizer as major reasons for the decline of soil fertility. Study by [6] reported that repeated cultivation, soil erosion, lack of manure, lack of fertilizer as the most farmers' perceived reasons of soil fertility decline in southern Ethiopia. Similarly, [15] reported runoff, no manure application, lack of fertilizer and deforestation as the most important suggested reasons for soil fertility loss in Umbulo catchment in southern Ethiopia. Maintaining soil fertility is the basis of all forms of sustainable land use, that is, land use that remains productive in the long term. If fertility has fallen below a critical level through long-term agricultural use without replacement of nutrients or as a result of erosion, or if it is naturally very low, the replenishment of soil fertility may be a precondition for productive agriculture [28]. Low and declining soil fertility are recognized by many tropical farmers as major constraints to agricultural production [29]. Generally, 75.7 percent of respondents' farm land didn't satisfy their family basic needs due to an increasing family size and degradation of farm land, while only 24.3 percent satisfied their family basic needs (Table 6).

Trees in crop fields can contribute to the maintenance and improvement of soil organic matter levels through increased inputs of litter and roots, reduction of soil temperatures through shading, and soil protection from erosion [28]. Some 20 years ago soil fertility was maintained predominantly by animal dung. In addition to animal dung, organic matter input to the soil consists of leaves of native trees. Currently, insufficient application of organic manure both from animal dung and from plants was mentioned as the major cause of declining soil fertility. All interviewed farmers suggested that the decline of soil fertility is mainly due to the decline of livestock in the systems. They also mentioned that insufficient manure and declining soil fertility arise from small farm sizes and poverty. The decline of soil fertility is generally perceived as a problem and most of farmers made some cognizant effort to maintain soil fertility by growing Vernonia amygdalina (Grawa), Croton macrostachyus (Bisana), Mellettia ferruginea (Birbira), and Cordia africana (Wanza) in their farmland. Studies in southern Ethiopia, [30] also reported that the decline of soil fertility is generally perceived as a problem and most of farmers made some conscious effort to maintain soil fertility by growing Millettia and Cordia.

\section{Conclusion}

This study was conducted to assess farmers' indigenous knowledge and perceptions on natural resource conservation and management in the Abo-Wonsho culturally protected forest area, Abo-Wonsho Woreda, Southern Ethiopia. Specifically, it was designed to identify farmers' local knowledge and their understanding on Abo-Wonsho culturally protected forest and to examine farmers' perception on management of Abo-Wonsho forest and farm management prac- 
tices and soil fertility just adjacent to the culturally protected forest, i.e. AboWonsho. The results revealed that the culturally protected forest area was primarily established by a person called "Abo" from which the name "Abo-Wonsho" was drived. In the study area, almost all the people of the residents around the area have been celebrating twice a year by slaughtering bulls, goats, sheep and hens and have been worshiping within the protected forest. As a result, most people have neither been sending the cattle in the forest area nor practice any agricultural activities within the protected forest due to fear of the spirit of "Abo", though very few of them have been started to collected firewood and using the area as grazing land following their religious changed to Catholic, protestant and orthodox Christian. The majority the respondents have known about the history and cultural practices of "Abo-Wonsho" and strongly believed that the area has been well maintained and protected for about 21 generations. They also believed that trees are still alive as a result of spiritual protection of "Abo", though some of them never agreed up on this due to increment deforestation from time to time. Still, most of the respondents perceived that the forest cover remained the same for the last many generation as a result of "Abo's" spiritual protection. In the study area, the responsibility of managing and protecting the forest falls fully on the shoulder of cultural leaders named as "Gana", "Woma", "Gadala" and "Karicho" without significant consideration of other ordinary farmers' role. In the cultural protected forest, almost all of the respondents were aware of the prohibition of cutting of trees and practicing any agricultural activities in the sacred place. However, the field observation revealed that farmers around the protected forest were encroaching towards the prohibited forest area for seeking of cultivation land and used to planting trees like eucalyptus tree species. In order to overcome human interferences within the culturally protected forest, the above mentioned cultural leaders have forcefully developed a mechanism called "Sera", meaning the exclusion of individuals from any kind of social interactions and involvements. Moreover, all of the surveyed households have accepted and agreed with this cultural rule. Despite the presence of the above cultural rule, the majority of the respondents confirmed that soil fertility decline, accelerating soil erosion, shortage of grazing land, shortage of firewood, loss of tree species, loss of wild animals species, changing in microclimate, and drying up of rivers and streams were the main consequences of deforestation that perceived by the respondents. However, all of them strongly believed that the problem of deforestation can be controlled through integration of cultural and modern participatory forest management systems. Therefore, local communities in the study area have shown that they are good managers of their natural resource base through their traditional ruling system and knowledge. Indigenous knowledge systems have been used in resource use and management since time immemorial by indigenous communities around the world [31] and Sidama "Sera" system is among the model indigenous natural resources management methods which have been practiced for decades. The study recom- 
mends that traditional rules and regulations regarding sustainable management of forest resources should be well maintained and support of regarding stakeholders is needed to strength the knowledge. Hence, as community-based natural resource management (CBNRM) is a major global strategy for the sustainable of management natural resources, attention should be given for awareness creation and integral use of indigenous knowledge and modern natural resources management system.

\section{Acknowledgements}

We are indebted to the farmers and enumerators who took part in the survey as well as the anonymous reviewers and the editors for their valuable comments and suggestions.

\section{Conflicts of Interest}

The author declares no conflict of interest.

\section{References}

[1] World Bank (2004) Indigenous Knowledge: Local Pathways to Global Development. Knowledge and Learning Center, World Bank, Africa Region, 282.

[2] World Bank (1998) Indigenous Knowledge for Development a Framework for Action. Knowledge and Learning Centre, World Bank, Africa Region, 46.

[3] Barrios, E. and Trejo, M.T. (2003) Implications of Local Soil Knowledge for Integrated Soil Management in Latin America. Geoderma, 111, 217-231. https://doi.org/10.1016/S0016-7061(02)00265-3

[4] Rohana, U., Nick, R., Garth, H. and Bantong, A. (2008) Indigenous Knowledge for Natural Resource Management: A Comparative Study of Maori in New Zealand and Dusun in Brunei Darussalam. GeoJournal, 73, 271-284. https://doi.org/10.1007/s10708-008-9198-9

[5] Dominics, D.A. and Fuchaka, W. (2016) Role of Indigenous Knowledge Systems in the Conservation of the Bio-Physical Environment among the Teso Community in Busia County-Kenya. African Journal of Environmental Science and Technology, 10, 467-475. https://doi.org/10.5897/AJEST2016.2182

[6] Tesfaye, B. (2003) Understanding Farmers: Explaining Soil and Wate Conservation in Konso, Wolaita and Wollo. Wageningen University, Wageningen.

[7] Andreas, K., Christoph, S., Stefan, S., Nigus, D.M., Feras, Z., Andreas, S. and Claudio, Z. (2018) Impact of Stone Bunds on Temporal and Spatial Variability of Soil Physical Properties: A Field Study from Northern Ethiopia. Land Degradation \& Development, 29, 585-595. https://doi.org/10.1002/ldr.2893

[8] Solomon, H. and Yoshinobu, K. (2006) Traditional Irrigation Management in Betmera-Hiwane, Ethiopia: The Main Peculiarities for Persistence of Irrigation Practices. Journal of Mountain Science, 2, 139-146. https://doi.org/10.1007/s11629-006-0139-0

[9] Kitessa, H. (2007) Traditional Forest Management Practices in Jimma Zone, South West Ethiopia. Ethiopian Journal of Education and Science, 2, 1-10. https://doi.org/10.4314/ejesc.v2i2.41982

[10] Melaku, G.J. (2016) Oromo Indigenous Knowledge and Practices in Natural Re- 
sources Management: Land, Forest, and Water in Focus. Journal of Ecosystem \& Ecography, 6, 2. https://doi.org/10.4172/2157-7625.1000181

[11] Alemayehu, W. (2007) Ethiopian Church Forests: Opportunities and Challenges for Restoration. Wageningen University, Wageningen, the Netherlands.

[12] Ethiopian National Meteorology Agency (ENMA) (2008) Meteorological Data. Addis Ababa, Ethiopia, 150.

[13] Sidama Zone Finance and Economic Development Sector (SZFEDS) (2007) Socio-Economic Study. Southern Nations Nationalities People Regional State, Ethiopia, 56.

[14] Bekele, T.A. (2007) Useful Trees of Ethiopia: Identification, Propagation and Management in 17 Agro Ecological Zones. RELMA in ICRAF Project, Nairobi, 552 p.

[15] Awdenegest, M. and Holden, N.M. (2007) Farmers' Perceptions of Soil Erosion and Soil Fertility Loss in Southern Ethiopia. Land Degradation and Development, 18, 543-554. https://doi.org/10.1002/ldr.795

[16] Ana, M.C. and Amélia, F.M. (2011) Importance of Local Knowledge in Plant Resources Management and Conservation in Two Protected Areas from Trás-osMontes, Portugal. Journal of Ethnobiology and Ethno Medicine, 7, 36. https://doi.org/10.1186/1746-4269-7-36

[17] Parrotta, J.A. and Agnoletti, M. (2007) Traditional Forest Knowledge: Challenges and Opportunities. Forest Ecology and Management, 249, 1-4. https://doi.org/10.1016/j.foreco.2007.05.022

[18] Puja, S., Masanori, K., Masahiro, T., Peter, N.K. and Hideyuki, M. (2007) Participation of Civil Society in Management of Natural Resources. International Review for Environmental Strategies, 7, 117-132.

[19] Pailler, S., Naidoo, R., Burgess, N.D., Freeman, O.E. and Fisher, B. (2015) Impacts of Community-Based Natural Resource Management on Wealth, Food Security and Child Health in Tanzania. PLoS ONE, 10, e0133252.

https://doi.org/10.1371/journal.pone.0133252

[20] Prompassorn, C., Nophea, S., Clemens, G., John, K.M.K. and Takuji, W.T. (2018) Influence of Indigenous Spiritual Beliefs on Natural Resource Management and Ecological Conservation in Thailand. Sustainability, 10, 2842. https://doi.org/10.3390/su10082842

[21] Shashi, M. (2017) Role of Traditional Practices in Conserving Environment: A Case of Manesar Village, Gurgaon. IOSR Journal of Humanities and Social Science, 22, 10-16.

[22] Rim-Rukeh, A., Irerhievwie, G. and Agbozu, I.E. (2013) Traditional Beliefs and Conservation of Natural Resources: Evidences from Selected Communities in Delta State, Nigeria. International Journal of Biodiversity and Conservation, 5, 426-432.

[23] Chandra, P.K. (2017) Conservation of Nature and Natural Resources through Spirituality. Applied Ecology and Environmental Sciences, 5, 24-34. https://doi.org/10.12691/aees-5-2-1

[24] Renzo, P.P. and Stuart, J.M. (2014) Impacts of Cattle Grazing on Forest Structure and Raptor Distribution within a Neotropical Protected Area. Biodiversity and Conservation, 23, 559-572.

[25] Girmay, G., Singh, B.R., Mitiku, H., Borresen, T. and Lal, R. (2008) Carbon Stocks in Ethiopian Soils in Relation to Land Use and Soil Management. Land Degradation and Development, 19, 351-367. https://doi.org/10.1002/ldr.844

[26] Nair, P.K.R. (1993) An Introduction to Agroforestry. International Centre for Re- 
search in Agroforestry (ICRAF). Kluwer Academic Publishers, The Netherlands.

[27] Gosai, K., Arunachalam, A., Dutta, B.K. and Prasanna, K.G.V. (2011) Indigenous Knowledge of Soil Fertility Management in the Humid Tropics of Arunachal Pradesh. Indian Journal of Traditional Knowledge, 10, 508-511.

[28] Schroth, G. and Sinclair, F.L. (2004) Trees, Crops and Soil Fertility: Concepts and Research Methods. European Journal of Soil Science, 55, 629-638.

[29] Smaling, E.M.A., Nandwa, S.M. and Janssen, B.H. (1997) Soil Fertility in Africa Is at Stake. In: Buresh, R.J., Sanchez, P.A. and Calhoun, F., Eds., Replenishing Soil Fertility in Africa, Soil Science Society of America, Madison, WI, 47-61.

[30] Azene, Z. and Agren, G.I. (2007) Farmers' Local Knowledge and Topsoil Properties of Agroforestry Practices in Sidama, Southern Ethiopia. Agroforestry System, 71, 35-48. https://doi.org/10.1007/s10457-007-9087-0

[31] Bekezela, M. (2009) Indigenous Knowledge Systems in the Use and Management of Natural Resources. A Case Study of Mopane Woodlands Resources in Nguwanyana Village of Mangwe District in Matabeleland South Province in Zimbabwe. 1-44. 